\title{
EFFECTS OF VITAMIN D SUPPLEMENTATION DURING PREGNANCY ON NEWBORNS AND INFANTS: AN INTEGRATIVE REVIEW
}

\section{Efeitos da suplementação de vitamina D durante a gestação no recém-nascido e lactente: uma revisão integrativa}

\author{
Letícia Veríssimo Dutra ${ }^{(\mathbb{B})}$, Fabíola Isabel Suano de Souza ${ }^{a}$ (D), Tulio Konstantynera,*
}

\section{ABSTRACT}

Objective: To identify the effects of vitamin D supplementation during pregnancy on newborns and infants.

Data sources: The present study is an integrative review of literature based on clinical trials published in journals indexed in the PubMed and Web of Science databases. Two searches were carried out, starting with the association (and) of the health term "vitamin D" with "pregnancy". In the search for information, selection criteria were established, and there was no language limitation and year of publication.

Data synthesis: The final selection resulted in 44 clinical trials, most of which were randomized and double blind, which were carried out in outpatient clinics, referral hospitals and universities, mainly in Europe. The samples studied were predominantly of newborns. In these 44 trials, 23 types of different doses of vitamin D during pregnancy, with different doses, regimens and times of use, and 14 different outcomes were studied in newborns (NB) and infants. Of the 44 studies performed, 35 showed statistically significant beneficial effects of vitamin $D$ supplementation during pregnancy on newborns and infants compared to control groups.

Conclusions: Vitamin D supplementation during pregnancy for at least three months before delivery has the potential of positively influencing calcium metabolism, physical growth and immune system development in newborns and infants. However, there is insufficient knowledge to define the optimal dose and to guarantee the absence of possible long-term adverse effects.

Keywords: Vitamin D; Pregnancy; Infant, newborn; Infant; Dietary supplements.

\section{RESUMO}

Objetivo: Identificar os efeitos da suplementação de vitamina D durante a gestação no recém-nascido e lactente.

Fontes de dados: Revisão integrativa da literatura baseada em ensaios clínicos publicados em revistas indexadas nas bases de dados PubMed e Web of Science. Foi realizada uma busca em cada base de dados, que partiu da associação (and) dos descritores de saúde vitamin D e pregnancy. Na busca pelas informações, foram estabelecidos critérios de seleção e não houve limitação de idioma nem de ano de publicação.

Síntese de dados: A seleção final resultou em 44 ensaios clínicosa maioria randomizada e duplo-cego - , que foram realizados em ambulatórios, hospitais de referência e universidades sobretudo da Europa. As amostras estudadas foram predominantemente de recém-nascidos. Nesses 44 ensaios, foram testadas 23 formas de suplementação de vitamina D na gestação, com diferentes doses, regimes e tempos de uso, e estudaram-se 14 desfechos diferentes nos recém-nascidos e lactentes. Dos 44 estudos, 35 demonstraram efeitos benéficos da suplementação de vitamina $D$ durante a gestação nos recém-nascidos e lactentes de forma estatisticamente significante, quando comparados aos do grupo controle.

Conclusões: A suplementação de vitamina D na gestação, por no mínimo três meses antes do parto, potencialmente influencia de forma positiva o metabolismo do cálcio, o crescimento físico e o desenvolvimento do sistema imunológico dos recém-nascidos e lactentes, entretanto não há conhecimento suficiente para a definição da dose ideal nem para garantir a inexistência de possíveis efeitos adversos em longo prazo.

Palavras-chave: Vitamina D; Gestação; Recém-nascido; Lactente; Suplementos naturais. 


\section{INTRODUCTION}

Vitamin D is a hormone that acts on bone metabolism and on the functioning of the immune, respiratory, endocrine, and cardiovascular systems. ${ }^{1}$ It can be obtained with endogenous synthesis and with a diet rich in foods such as fatty fish (for example, tuna and salmon), which contain cholecalciferol (vitamin D3), and plants and fungi, which have ergocalciferol (vitamin D2). ${ }^{1,2}$ The human body has sun exposure as its main source of synthesis (vitamin D3) and, to a lesser extent, food (vitamins D3 and D2).

Sun exposure allows 7-dehydrocholesterol, synthesized by cholesterol, ${ }^{2}$ located in the bilipid layers of cell membranes of epidermis, when receiving ultraviolet $B$ (UVB) radiation, to promote the relocation of electrons in carbons 9 and 10 of ring $\mathrm{B}$, causing its opening. ${ }^{1}$ This new molecule conformation is called pre-vitamin $\mathrm{D} 3$, which, being unstable, undergoes isomerization promoted by heat, resulting in the creation of vitamin D3. ${ }^{1}$

Cholecalciferol undergoes changes until it reaches its active form. First, it is transported to the liver, undergoing the first hydroxylation at carbon 25 , by the enzyme 25 -hydroxylase, transforming into $25(\mathrm{OH}) \mathrm{D}$, an inactive form abundantly found in bloodstream. The second hydroxylation occurs in the kidney, with the action of the $1 \alpha$-hydroxylase enzyme, transforming into $1.25(\mathrm{OH})_{2} \mathrm{D}$, metabolically active form. ${ }^{1}$

Vitamin D deficiency and insufficiency is a worldwide public health problem that affects about one billion people of all ages, genders, and geographic regions of the world., This deficiency is highly prevalent, especially in risk groups, such as pregnant women and children. ${ }^{3}$

The prevalence of vitamin D deficiency and insufficiency during pregnancy can reach 96 and $99.4 \%$, respectively. ${ }^{5,6}$ These proportions have been associated to pregnancy-specific hypertensive disease, gestational diabetes mellitus, cesarean delivery, infectious diseases, and premature childbirth. ${ }^{7}$ For their descendants, there is an association between this deficiency and restricted intrauterine growth, type 1 diabetes mellitus, asthma, and inflammatory disorders. ${ }^{4}$ In infants, vitamin D deficiency is also common in several countries, whose prevalence reaches about $50-70 \%$ of them in the United States and $60 \%$ in Brazil.

Adequate levels of vitamin D $(25(\mathrm{OH}) \mathrm{D})$ are considered to be above $30 \mathrm{ng} / \mathrm{mL}(75 \mathrm{nmol} / \mathrm{L})$, for insufficiency, between 21-29 ng/mL (51-74 nmol/L), and, for deficiency, concentrations under $20 \mathrm{ng} / \mathrm{mL}(50 \mathrm{nmol} / \mathrm{L}) .^{5}$

Studies have linked 25(OH)D supplementation to benefits to pregnancy and the fetus, such as reduced risk of infection, decreased risk of small newborns for gestational age, asthma, sepsis, and prematurity. ${ }^{7}$ Despite research showing benefits of vitamin D supplementation during pregnancy, the results are not unanimous and there is no comparison of the methods used by each of them, which limits the routine recommendation of this supplementation by the World Health Organization. ${ }^{8}$ Specifically in Brazil, there are no representative population data to justify preventive vitamin $\mathrm{D}$ supplementation for all pregnant women, despite being considered a developing country, and the existence of regional studies that show low consumption and high prevalence of vitamin $\mathrm{D}$ deficiency/insufficiency in pregnant women. ${ }^{7}$

Thus, the aim of the present study was to identify the effects of vitamin D supplementation during pregnancy on health outcomes of newborns and infants.

\section{METHOD}

The present study is an integrative review ${ }^{9}$ and followed the guidelines of the Preferred Reporting Items for Systematic Reviews and Meta-Analyzes (PRISMA) (http://www.prisma-statement.org) for the selection of scientific articles. The search for information of interest was carried out in the international databases PubMed and Web of Science, in which articles were selected until December 2019, in order to identify the studies that evaluated vitamin $\mathrm{D}$ supplementation during pregnancy and their effects on newborns (NBs) and infants.

Inclusion criteria for articles were the appearance in searches according to the terms used, and the assessment of newborns and infants. In addition to the duplicity between the searches carried out, exclusion criteria were included in the study selection process: research that did not supplement pregnant women, observational designs, review articles, duplicate articles between the bases, letters to the editor, editorial materials, meeting abstracts, articles procedures, comments, research that supplemented multiple nutrients, case reports, editorial notes, and research in non-humans. Besides that, articles that did not assess the effects of vitamin D supplementation on pregnancy in newborns and infants were excluded.

Thus, in the PubMed database, the terms of the Medical Subject Headings (MeSH) vitamin D and pregnancy (vitamin D and pregnancy) were used, with 2,828 articles found. By using the filters age for age was born 23 months ago and clinical trial (infant birth-23 months and clinical trial), the publications found were reduced to 80 articles (Figure 1).

In the Web of Science database, the words vitamin D and pregnancy (vitamin D and pregnancy) were used, with 3,894 articles found. After this stage, three different strategies were carried out:

- Use of the filter pediatrics, which generated 333 articles.

- Addition of the infant term, generating 778 articles

- Addition of the infant, newborn, term with the generation of 166 more articles. 


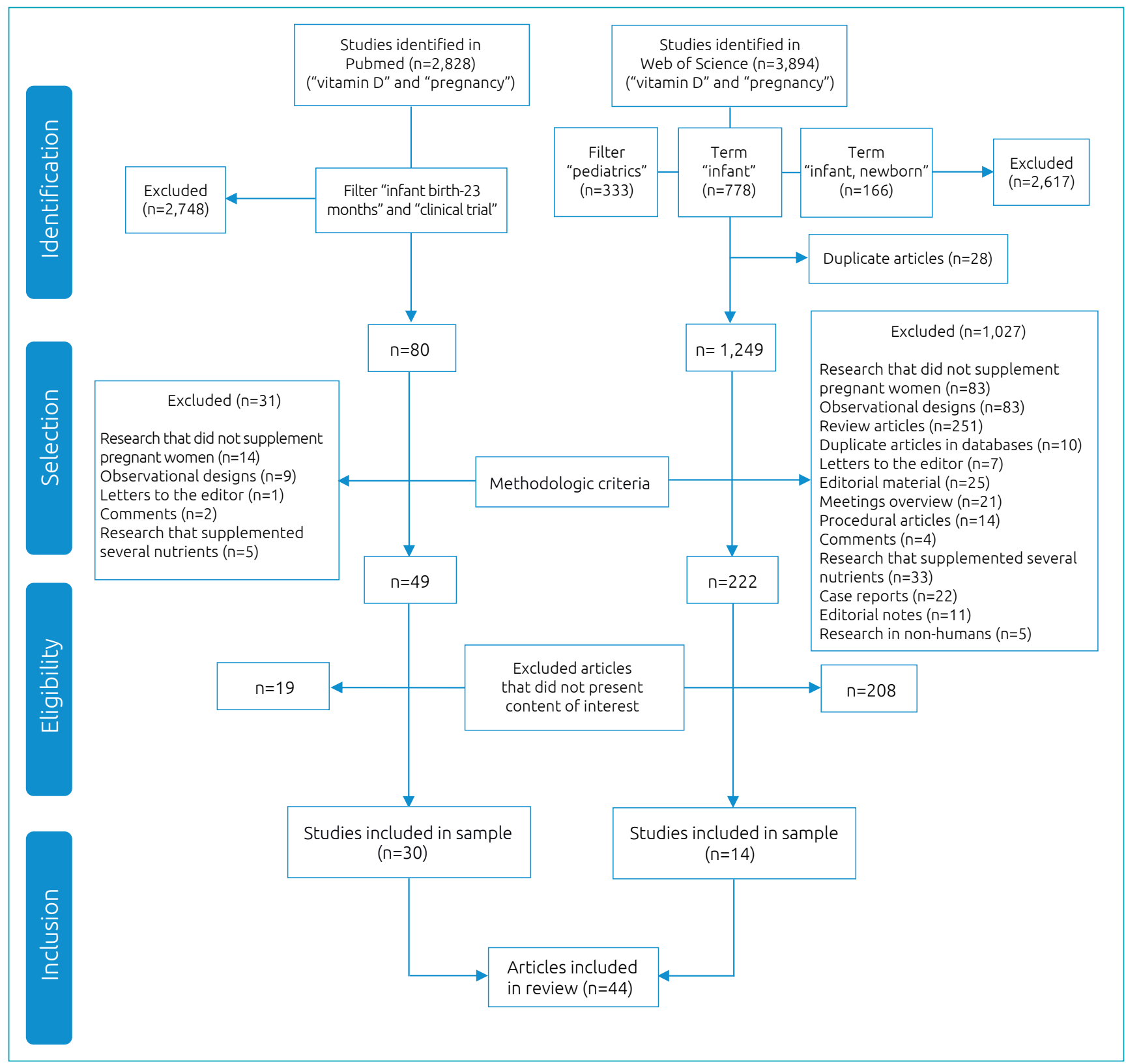

Figure 1 Flowchart of the integrative review process.

Thus, the total was 1,277 articles. Of these, 28 studies that appeared in more than one of the three strategies were excluded (Figure 1).

At this stage, searches in the two databases resulted in the initial selection of 1,329 searches, which were evaluated for their methodological characteristics.

The selection of articles was made by two reviewers, independently, from the search in the databases to the reading and selection of titles, abstracts, and articles in full. At the end of each selection stage, disagreements were decided by consensus between both professionals. Of the 1,329 studies, 31 were excluded from PubMed and 1,027 from Web of Science, as they did not meet the established methodological criteria, resulting in 271 articles.

In the eligibility stage, these 271 articles were assessed for the existence of content of interest (evaluation of the effects of vitamin $\mathrm{D}$ supplementation during pregnancy on newborns and infants). Those who did not have information to answer the research question were excluded (19 from PubMed and 208 from Web of Science).

Finally, 44 articles were included in the review to compare and interpret their results. Figure 1 shows the article selection process. 


\section{RESULTS}

The method used to search for information of interest resulted in 44 randomized clinical trials. These studies were carried out between the years 1980 to 2019, involving 10,401 pregnant women with an average vitamin $\mathrm{D}$ supplementation time of 19 weeks and were carried out in outpatient clinics, referral hospitals, and universities in 15 different countries worldwide.

The reference levels of vitamin $\mathrm{D}$ concentrations used in most studies were in accordance with the guidelines of the Brazilian Society of Endocrinology and Metabology (, ${ }^{5}$ defined as sufficiency $\geq 30 \mathrm{ng} / \mathrm{mL}$ ( $75 \mathrm{nmol} / \mathrm{L}$ ), insufficiency between 20 and $29 \mathrm{ng} / \mathrm{mL}$ ( 50 and $74 \mathrm{nmol} / \mathrm{L}$ ), and deficiency $<20 \mathrm{ng} / \mathrm{mL}$ $(50 \mathrm{nmol} / \mathrm{L}) .^{5} \mathrm{~A}$ total of 23 forms of vitamin D supplementation during pregnancy were studied, with different doses, regimens, and times of use. Doses ranged from 200 to 200,000 IU of vitamin $\mathrm{D}$, averaging approximately $1,750 \mathrm{IU} /$ day, 30,700 IU/week, 60,000 IU/month, 111,500 IU/single dose, 85,000 IU/two doses, and 120,000 IU/four doses.

The studies evaluated the effect of vitamin D supplementation during pregnancy on 14 health outcomes in newborns and infants: length, weight, and head circumference at birth (nine studies), ${ }^{10-18}$ vitamin D concentration (22 studies), ${ }^{18-39}$ calcium concentration, bone and dental health (seven studies), ${ }^{14,18,39-43}$ respiratory disease and wheezing (respiratory tract infections) (five studies), ${ }^{44-48}$ use of health services (one study), ${ }^{49}$ DNA methylation (two studies), ${ }^{47,50}$ genetic variations of vitamin D-binding protein (one study), 51 insulin-like growth factor (IGF) at birth (one study) ${ }^{52}$, and instestinal microbiota (one study). ${ }^{53}$ The studied samples were predominantly composed of newborns.

Of the 44 trials selected, vitamin $\mathrm{D}$ supplementation during pregnancy showed a statistically significant association with at least one of the outcomes assessed in 35 studies. ${ }^{12,16-22,24-42,44-48,50-53}$ In relation to anthropometric outcomes, the effects were: greater length, ${ }^{16,18}$ weight ${ }^{16}$ and head circumference at birth ${ }^{16}$, and greater linear growth in the first year of life. ${ }^{12}$

The doses of 1,000 to $4,000 \mathrm{IU} /$ day, 14,000 to $35,000 \mathrm{IU} /$ week, and 50,000 IU/month of vitamin D3 were identified as the minimum necessary to ensure adequate concentrations of vitamin D in early childhood. ${ }^{12,25-31,33-36,38,53}$

Regarding the calcium concentration and bone pattern, doses of 50,000 IU/week in deficient pregnant women resulted in adequate calcium concentrations in newborns. In addition, they guaranteed plasma concentrations of $25(\mathrm{OH}) \mathrm{D}$ above $20 \mathrm{ng} / \mathrm{mL}$ in the umbilical cord without inducing hypercalcemia. ${ }^{19,22,39}$ The study that evaluated tooth enamel and caries did not show statistically significant results. ${ }^{43}$ Three studies supplemented vitamin D with calcium during pregnancy. In one of them, calcium did not interfere in their results, ${ }^{40}$ but in the other studies, this combined supplementation resulted in greater adequacy of anthropometric measurements. ${ }^{12,16,18}$ Supplementation of vitamin D isolated during pregnancy did not influence the bone patterns of newborns. ${ }^{14,40-42}$

Some studies have associated maternal vitamin D supplementation to respiratory diseases. ${ }^{44-45,47}$ Grant et al. showed an association with the reduction in the proportion of children sensitized to mites at 18 months of age..$^{45}$ Another research carried out in 2015 showed an association with the reduction in the number of primary care consultations for acute respiratory infection during early childhood, ${ }^{44}$ and Mirzakhani et al. indicated an association with lower risk of wheezing in childhood. ${ }^{47}$

More specifically, two studies evaluated the association of vitamin $\mathrm{D}$ supplementation during pregnancy with a concentration of $25(\mathrm{OH}) \mathrm{D}$ in newborns by group of mothers, according to genetic variations of vitamin $\mathrm{D}$ transporter. ${ }^{48,51}$

Finally, a recent investigation found that vitamin D supplementation during pregnancy at a dose of 3,800 IU/day showed epigenetic alteration (DNA methylation in cytosine-guanine dinucleotides - CpGs) in breastfed newborns aged 4 to 6 weeks of age, in which genes that underwent methylation alterations were associated to collagen metabolic processes and regulation of apoptosis. ${ }^{50}$

Regarding interventions tested in the 44 trials, seven started vitamin $\mathrm{D}$ supplementation in the first trimester of pregnancy, ${ }^{18,27,37,38,47,51,53} 21$ in the second, ${ }^{13,15-17,22,25,26,28,29,31-33,36,40-43,46,48,50,52}$ and 16 in the third. ${ }^{10-}$ 12,14,19-21,23,24,30,34,35,39,44,45,49 The studies that started supplementation in the first trimester found a statistically significant difference in weight,${ }^{18}$ height, ${ }^{18}$ fontanelle size,${ }^{18}$ vitamin D2 concentration, ${ }^{7,37,38,51}$ and wheezing in the first year of life. ${ }^{47}$ Studies that initiated supplementation in the second trimester showed statistically significant differences between groups, related to the outcomes of vitamin D concentration, ${ }^{22,25,26,28,29,31-33,36}$ bone health, ${ }^{41,42}$ anthropometry, ${ }^{16,17}$ and risk of persistent wheezing. ${ }^{46}$ In turn, research on supplementation from the third trimester onwards resulted in statistically significant differences regarding the outcomes of vitamin D concentration, ${ }^{19-21,24,30,34,35}$ calcium concentration, ${ }^{29}$ and respiratory infections. ${ }^{44,45}$

On the other hand, two of the selected studies showed results of adverse events: one of them found maternal hypercalcemia, ${ }^{29}$ and the other, neonatal hypercalcemia. ${ }^{39}$

The year of publication, the methodological characteristics and the main results of the 44 selected studies are described in Tables 1, 2 and 3, which were organized according to the different outcomes studied: effect of vitamin D supplementation on concentrations of $25(\mathrm{OH}) \mathrm{D}$ (Table 1), growth and bone pattern (Table 2), and other clinical and laboratory outcomes in the child (Table 3). 


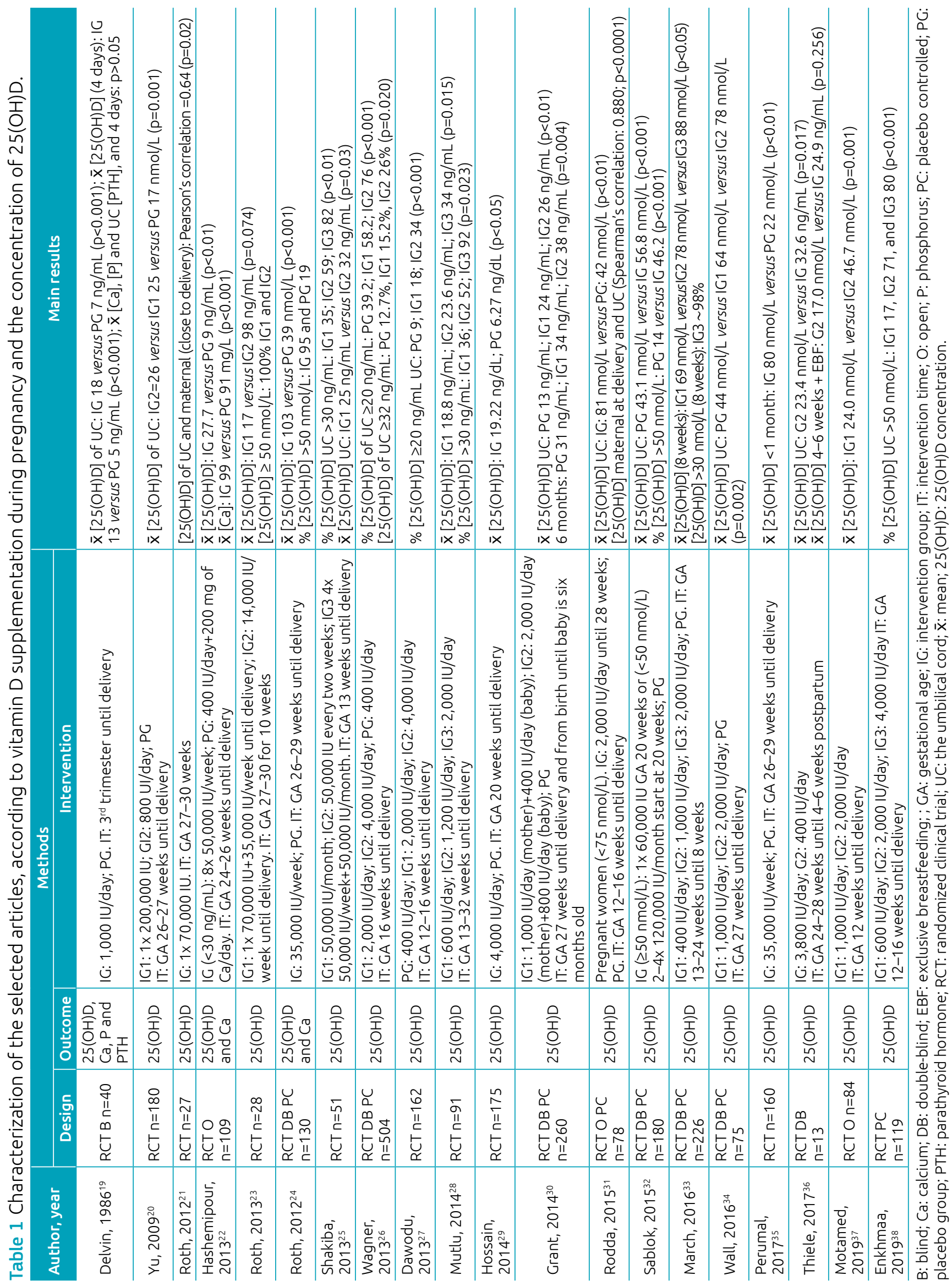




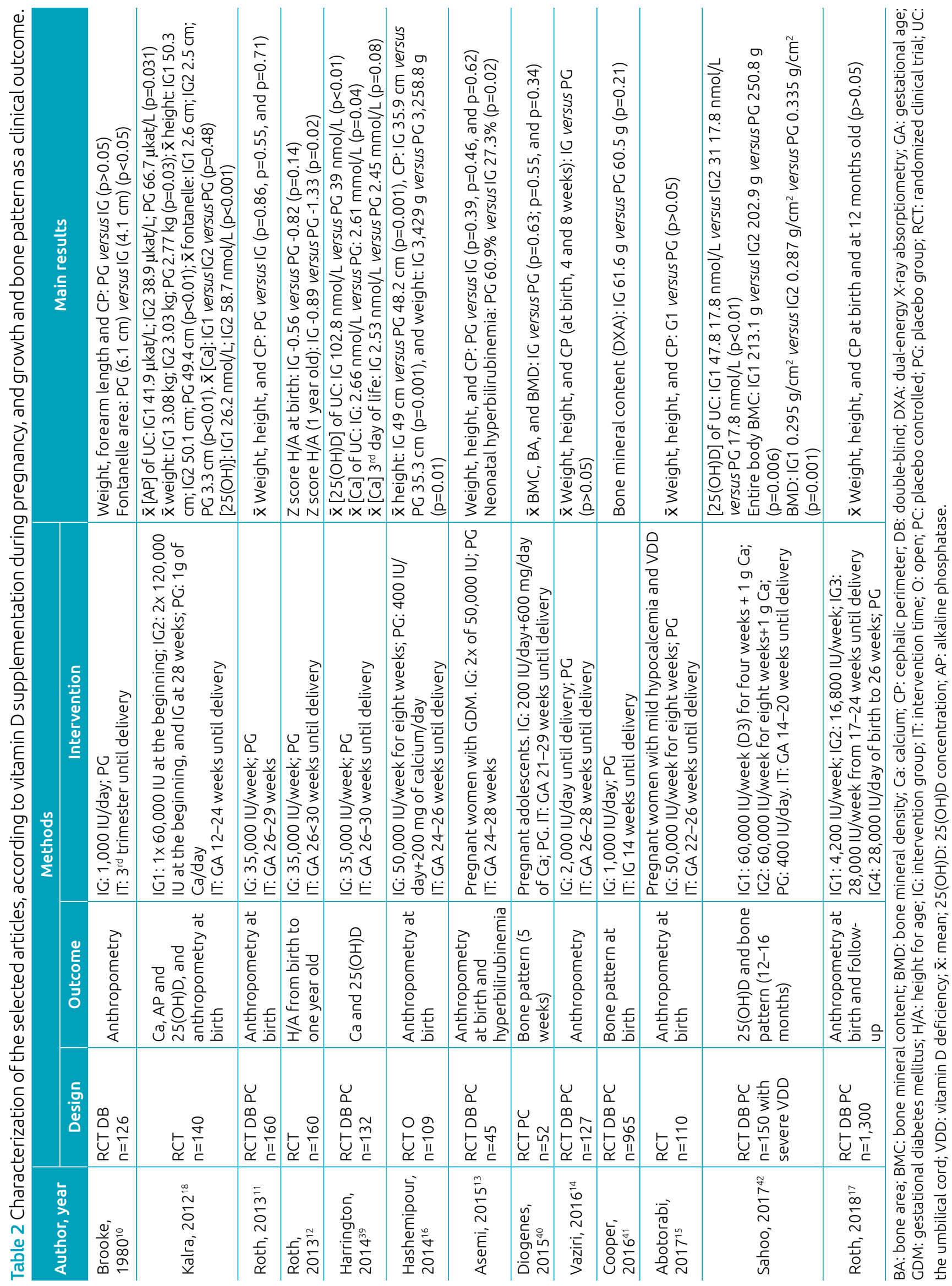




\begin{tabular}{|c|c|c|c|c|c|c|c|c|c|c|c|c|}
\hline 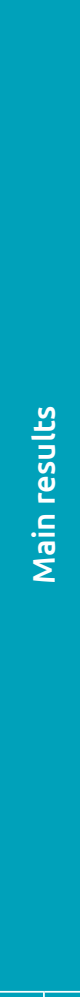 & 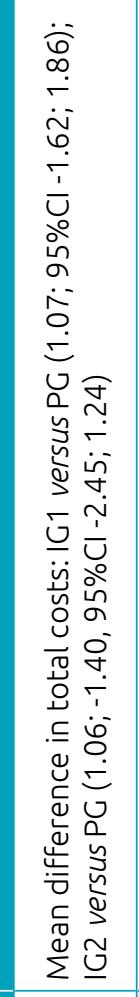 & 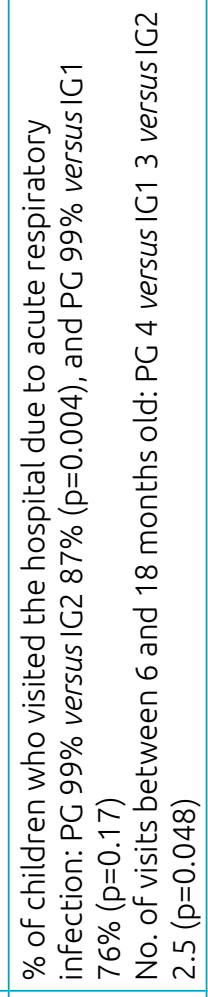 & 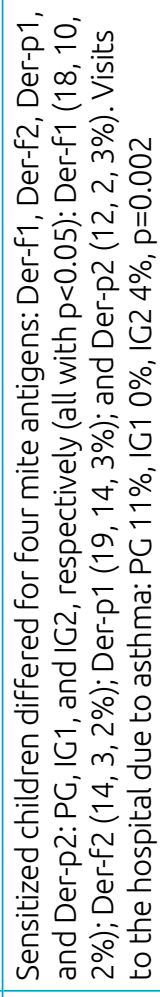 & 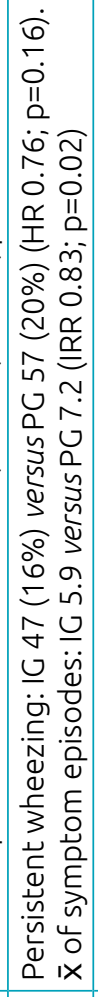 & 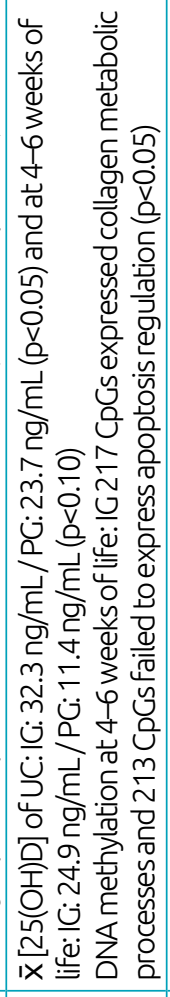 & 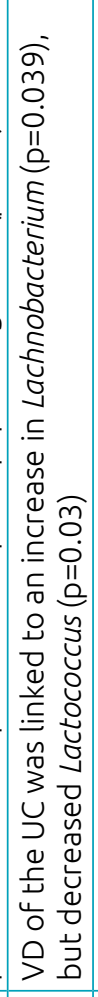 & 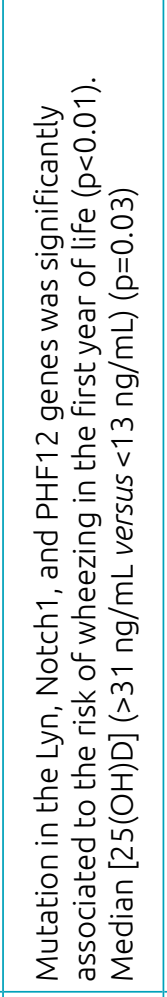 & 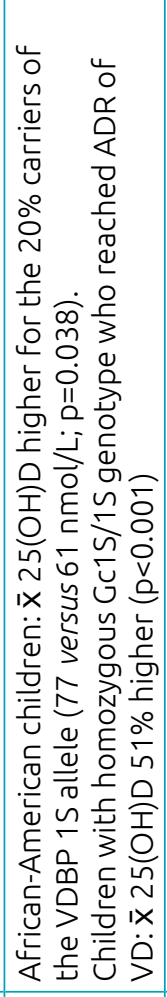 & 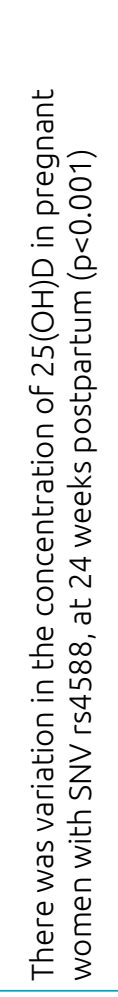 & 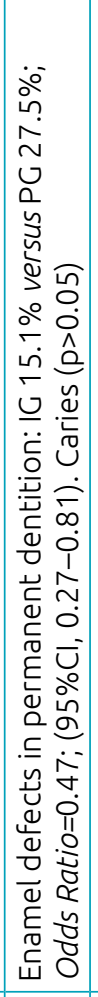 & 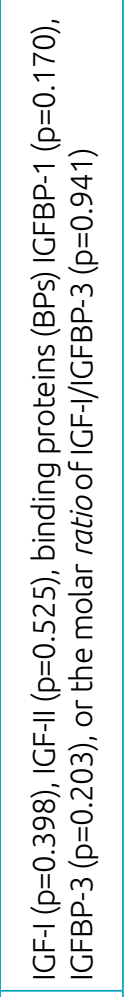 & 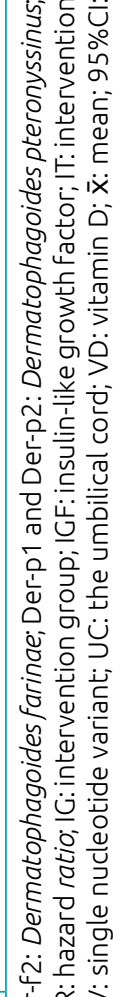 \\
\hline 능 & 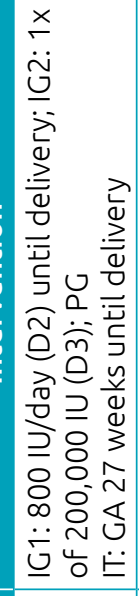 & 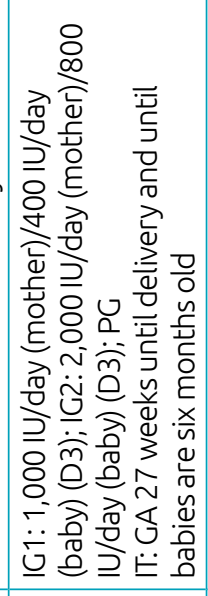 & 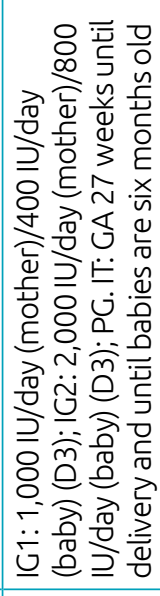 & 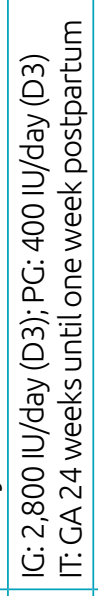 & 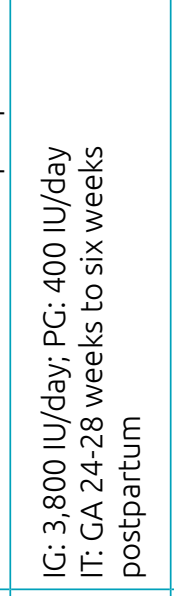 & 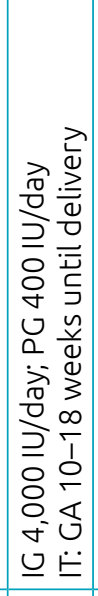 & 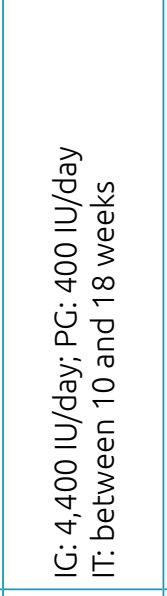 & 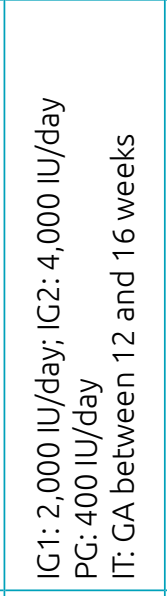 & 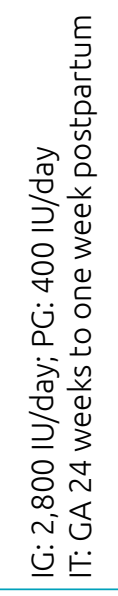 & 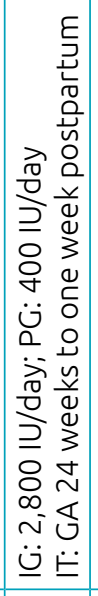 & 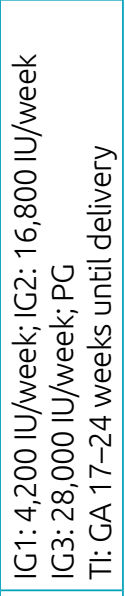 & \\
\hline & 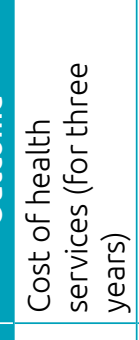 & 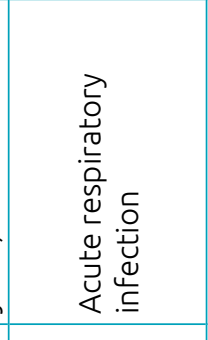 & 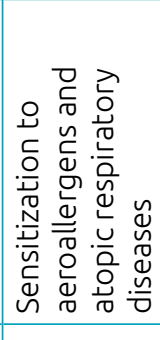 & 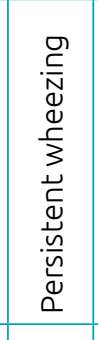 & 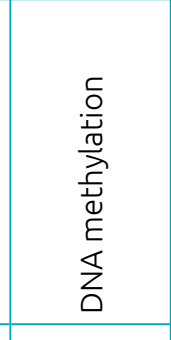 & 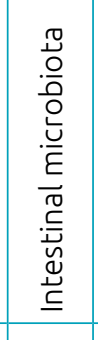 & 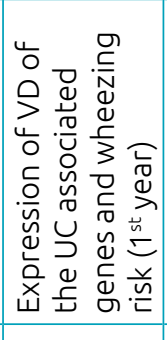 & 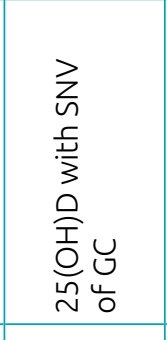 & 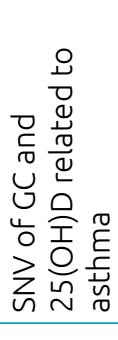 & 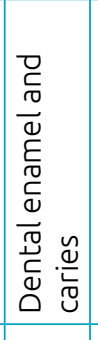 & 5 & \\
\hline & $\begin{array}{l}\cup \\
\swarrow \\
\longleftarrow \\
\simeq\end{array}$ & 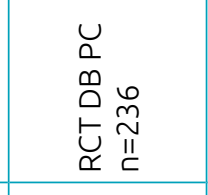 & 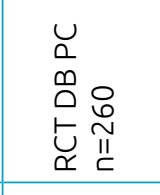 & 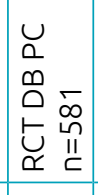 & 峁。 & 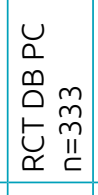 & $\begin{array}{l}0 \\
\text { m } \\
0\end{array}$ & ? & 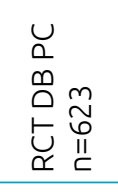 & 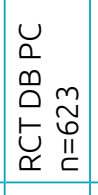 & 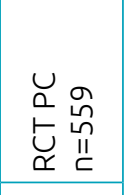 & \\
\hline 至 & 离 & 는 & 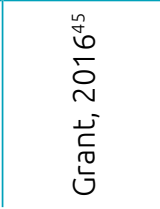 & $\sum_{0}^{0} \underbrace{0}_{0}$ & 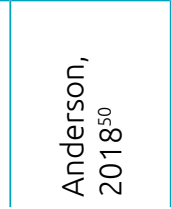 & 愛 & $\frac{\frac{1}{v}}{\stackrel{0}{N}}$ & $\begin{array}{l}0 \\
3 \\
0 \\
z \\
z\end{array}$ & ○ & 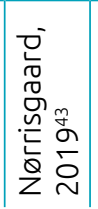 & & \\
\hline
\end{tabular}




\section{DISCUSSION}

In the 44 clinical trials included in the present review, 23 forms of vitamin D supplementation during pregnancy were studied, with varying moments, doses, regimens and times of use, and 14 different types of outcomes in children. Of these studies, 35 demonstrated benefits of this supplementation for children, when compared to the control group.

Although all studies are randomized clinical trials, several methods were used, regarding sample, type and dose of vitamin $\mathrm{D}$, gestational period, intervention time, and outcome measured. The dosage of 2,000 IU/day of vitamin D3 was the most used and the one that most resulted in statistically significant differences in the studied outcomes. . $^{14,25-27,30,31,33,34,37,38,44,45,51}$

The present study was an integrative review and was based on a careful and sensitive methodology of searching for information of interest in two databases of recognized quality of scientific knowledge production. ${ }^{9}$ The strategy started by crossing health terms, which minimizes the loss of research that studied the topic. In addition, the choice of clinical trials, which are the ideal study design for identifying the effects of interventions, enabled the interpretation of findings with less influence from possible confounding factors. ${ }^{9}$ Although two databases of worldwide scope composed of high impact journals were included, other studies published in journals indexed in other databases were not included here.

Of the analyzed articles, most part supplemented vitamin D during the second ${ }^{13,15-17,22,25,26,28,29,31-33,36,40-43,46,48,50,52}$ and the third $^{10-12,14,19-21,23,24,30,34,35,39,44,45,49}$ trimester of pregnancy, thus finding positive associations with their outcomes. This fact can be explained by the greater transfer of $25(\mathrm{OH}) \mathrm{D}$ to the fetus via the transplacental route in the last months of pregnancy, which is the main source of this vitamin to newborns in their first months of life. ${ }^{7}$ In addition, the placenta contains a vitamin $\mathrm{D}$ receptor and produces the enzyme $1 \alpha$-hydroxylase, which converts $25(\mathrm{OH}) \mathrm{D}$ to its active form and, consequently, increases the supply of vitamin $\mathrm{D}$ to the fetus. ${ }^{7}$

Most studies administered vitamin D3 because, as already known, vitamin D molecules (D2 and D3) differ not only in plant and animal origin/sun exposure, respectively, but in that they have differences in their structure - vitamin D2 has one more carbon (28 carbons) than vitamin D3, an extra methyl group and a double bond between carbons 22 and 23. Vitamin D2 also presents only one third to half of the biological potency of vitamin D3 to be converted into $25(\mathrm{OH}) \mathrm{D} .{ }^{1}$ Therefore, vitamin D3 was the main choice of supplementation administration among the trials. Mothers are the only source of vitamin $\mathrm{D}$ for their fetuses during pregnancy, which is made available by the placenta, the most important extrarenal site for converting $25(\mathrm{OH}) \mathrm{D}$ into $1.25(\mathrm{OH})_{2} \mathrm{D}$ in pregnant women, by the high activity of the $1 \alpha$-hydroxylase enzyme. Therefore, maternal and fetal concentrations are directly related. ${ }^{2}$

Of the analyzed outcomes, the concentration of vitamin $\mathrm{D}$ in newborns was the most studied. All 23 selected studies that evaluated this outcome ${ }^{18-39,50}$ showed concentrations of $25(\mathrm{OH}) \mathrm{D}$ of cord significantly higher than those of the control groups, with no contradictions regarding the benefit of vitamin D supplementation during pregnancy, even with different times, doses, regimens, and time of use. Most of these studies tested a dose of 2,000 IU per day,,$^{26-28,30-31,33,34,37,38}$ but others used smaller daily or weekly, monthly and single doses. Despite the positive results with different times and regimens of use, daily doses of at least 1,000 IU were effective in increasing the concentrations of $25(\mathrm{OH}) \mathrm{D}$ in newborns. Specifically, the study that included 119 pregnant women from Mongolia demonstrated that daily doses of 2,000 and 4,000 IU, from the second trimester, were not only sufficient to achieve adequate concentrations of vitamin $\mathrm{D}$ in mothers and their newborns, but also safe. ${ }^{38}$ Such evidence shows that the most cost-effective daily dose of vitamin $\mathrm{D}$ supplementation during pregnancy should not exceed 4,000 IU.

Of the studies that analyzed growth and bone patterns, ${ }^{12,18,19,39,41}$ four of them evaluated calcium concentrations, and weekly doses of 35,000 to 50,000 IU of vitamin $\mathrm{D}$ during pregnancy were needed to achieve the highest concentrations in newborns in the intervention group compared to the control. ${ }^{18,22,24,39}$ In one of the studies, pregnant women with vitamin $\mathrm{D}$ deficiency participated, and they also received calcium supplementation. ${ }^{22}$

As to bone patterns, four studies analyzed bone density or mineral content, ${ }^{14,40-42}$ and maternal vitamin D supplementation did not influence these outcomes in the newborns or infants studied. In addition, of the eight studies that examined anthropometric indices at birth, ${ }^{10-17}$ only one of them ${ }^{16}$ found greater length, head circumference, and weight in the group that received vitamin D supplementation during pregnancy. Such difference may be related to the fact that this was the only study that supplemented vitamin $\mathrm{D}$ associated with calcium in pregnant women with vitamin $\mathrm{D}$ deficiency, using a high dose (50,000 IU per week for eight weeks).

These findings suggest that vitamin $\mathrm{D}$ supplementation during pregnancy to improve bone pattern of newborns potentially benefits only pregnant women with vitamin $\mathrm{D}$ deficiency and those with the need for adequate calcium consumption. This finding corroborates the final message of a systematic review that included 76 studies, compared concentrations of vitamin D during pregnancy and outcomes in newborns, and concluded that evidence was insufficient to recommend routine supplementation for pregnant women. ${ }^{55}$ 
Vitamin D plays a skeletal role, requiring higher concentrations of calcium to promote the appropriate bone pattern. It also participates in skeletal metabolism, promoting bone mineralization and renal reabsorption of calcium and phosphorus. By reducing blood calcium concentrations, there is an increase in parathyroid hormone $(\mathrm{PTH})$ synthesis and renal production of $1.25(\mathrm{OH})_{2} \mathrm{D}$. During pregnancy, plasma calcium concentrations increase, due to the greater need for calcium for fetal skeletal development, with the production of $1.25(\mathrm{OH})_{2} \mathrm{D}$ by the placenta and the action of its vitamin D receptor (VDR), which does not depend on $\mathrm{PTH},{ }^{55}$ justifying the increased need for calcium in this period.

Studies that evaluated acute respiratory infection and sensitivity to aeroallergens found lower frequencies of these events associated to vitamin D supplementation during pregnancy, which can indicate and reinforce the immunomodulatory effect of this micronutrient. Vitamin D stimulates most immune cells, making them capable of promoting this effect. ${ }^{4}$ Its supplementation during pregnancy is linked to decreased risk of sepsis in newborns, which can be explained by the increase in LL-37 catelicidin levels (antimicrobials), as shown by Turkish and Danish studies with infants who had early-onset neonatal sepsis and deficiency in postpartum vitamin D levels. ${ }^{5}$ Moreover, the Vitamin D Antenatal Asthma Reduction Trial (VDAART), in the United States, demonstrated that supplementation of 4,000 IU/day of vitamin D3 reduced the incidence of wheezing in newborns. ${ }^{4}$ Such findings corroborate the results of the studies selected in this review: vitamin D supplementation during pregnancy positively regulated airways' immune profile.

The actions of $1.25(\mathrm{OH})_{2} \mathrm{D}$ are mediated by its VDR, encoded by the gene of the same name VDR (gene ID 7421), which is present in almost all human cells and participates in the protein synthesis of about 5 to $10 \%$ of the human genome, which can promote hereditary changes in gene expression that are not mediated by changes in the DNA sequence, a phenomenon known as epigenetics. ${ }^{2}$ In this context, vitamin $\mathrm{D}$ supplementation in pregnancy altered the methylation of cytosine-guanine dinucleotides, which may associate with collagen metabolic processes and the regulation of apoptosis. Studies show that vitamin D deficiency during pregnancy alters epigenetics and gene expression, contributing to complications during pregnancy and regarding the baby. ${ }^{54}$ Hollis et al. found that vitamin $\mathrm{D}$ supplementation during pregnancy at doses that ensure that plasma concentrations of $25(\mathrm{OH}) \mathrm{D}$ reach $40 \mathrm{ng} /$ $\mathrm{mL}$ children is related to epigenetic regulation, but with no results on the effects on clinical events of this long-term supplementation in children. ${ }^{1}$

We identified only one study that evaluated the effect of daily supplementation of $4,000 \mathrm{IU}$ of vitamin D on the intestinal microbiota, showing quantitative changes in some bacteria. Despite the change in microbiota composition and the biological plausibility pointed out by the authors, it is too early to consider the beneficial effect of this supplementation in the long term..$^{53}$

During pregnancy, physiological changes occur, such as the increase in plasma volume, which begins in the first trimester and persists until delivery. ${ }^{54}$ This hemodilution occurs in disproportion to the erythrocyte volume even with adequate nutritional reserves, which results in changes in the needs of vitamins and minerals. ${ }^{54}$

Another point that influences the physiological changes of pregnancy and modifies the micronutrient needs is the affinity with plasma proteins. Vitamin D may be free, bound to albumin and, more often, vitamin D-binding protein (VDBP). VDBP concentrations influence the availability of $25(\mathrm{OH}) \mathrm{D}$; linked to it, reduce the concentration of $25(\mathrm{OH}) \mathrm{D}$ free for biological activity. DBP is the main binding protein of $25(\mathrm{OH})$ $\mathrm{D}$ and $1.25(\mathrm{OH})_{2} \mathrm{D}$ and is encoded by the GC gene. In addition, its variants can alter the binding affinity and concentration of $25(\mathrm{OH}) \mathrm{D} .{ }^{54}$

The placenta is the main extrarenal site to convert $25(\mathrm{OH}) \mathrm{D}$ into $1.25(\mathrm{OH})_{2} \mathrm{D}$ in pregnant women, due to the high activity of the enzyme $1 \alpha$-hydroxylase. Maternal vitamin $\mathrm{D}$, therefore, is directly related to fetal vitamin $\mathrm{D}$ concentrations. ${ }^{6,55}$ Adequate levels of vitamin $\mathrm{D}$ in pregnant women must be greater than $30 \mathrm{ng} / \mathrm{mL},{ }^{6}$ however Hollis et al. suggest that to reach sufficient concentrations of $25(\mathrm{OH}) \mathrm{D}$ for the fetus, blood levels of $100 \mathrm{nmol} / \mathrm{L}$ ( 40 $\mathrm{ng} / \mathrm{mL}$ ) are required, because the conversion of $25(\mathrm{OH})$ $\mathrm{D}$ to $1.25(\mathrm{OH})_{2} \mathrm{D}$ in pregnant women it is not as directly proportional as in non-pregnant women. ${ }^{2}$

In Brazil, the Brazilian Society of Endocrinology and Metabology (, based on the Institute of Medicine and the Endocrine Society, recommends $600 \mathrm{IU} /$ day of vitamin D during pregnancy, but there are still no population data to recommend exact doses of vitamin $\mathrm{D}$ to this group specifically. ${ }^{5}$ Some countries and international scientific organizations suggest supplementing pregnant women with doses of vitamin D ranging from 400-600 IU/day (Institute of Medicine and Royal College of Obstetricians and Gynaecologists) and 1,500 2,000 IU/day (Endocrine Society and Canadian Society of Endocrinology and Metabolism). ${ }^{5}$ Despite growing evidence showing the high prevalence of vitamin D deficiency among pregnant women and the normalization of these concentrations, with drug supplementation, being associated with some favorable outcomes, as demonstrated by the present review, the World Health Organization does not yet advocate universal supplementation for this population. ${ }^{6}$ 
Although all studies included in this review are randomized clinical trials, methodological differences and limitations were identified between the studies, which can interfere in the comparability and interpretation of results and, consequently, decrease their reliability. Of the limitations identified, the main ones were small sample size, loss of follow-up of participants, and the ethnic homogeneity of samples. In this sense, skin color stands out as a possible selection bias, which was not considered in most studies and directly influences the vitamin D concentration, given that the greater amount of melanin in skin interferes with the endogenous synthesis of vitamin $\mathrm{D}$ (7-dehydrocholesterol for vitamin D3), blocking UVB rays and increasing the risk of deficiency. ${ }^{1}$ Only two studies, one multicentric and one carried out in Brazil, selected heterogeneous samples.

The present review identified the existence of beneficial clinical outcomes of vitamin D supplementation in pregnant women and their effects in children, which are potentially associated to baseline concentrations of pre-pregnancy vitamin D, and the time and dose of supplementation. However, these studies should be interpreted with care, as few have evaluated the same outcomes. Thus, there is not enough data to support a definitive conclusion.
In this context, the results presented here suggest that vitamin $\mathrm{D}$ supplementation for at least three months before delivery results in an increase in vitamin D levels in newborns. In addition, it prevents the occurrence of acute respiratory infection and sensitivity to aeroallergens in newborns and infants. Despite biological plausibility, this intervention did not positively influence calcium metabolism or physical growth, except when performed on pregnant women with vitamin D deficiency. Even though favorable evidence points to the use of this supplement, the ideal dose and possible long-term adverse effects cannot yet be stated. Therefore, further studies are needed to confirm the beneficial effects of vitamin D supplementation during pregnancy and to define the best form of use (time, dose, regime, and time), considering the particularities of vitamin $\mathrm{D}$ metabolism during pregnancy, the individuality of pregnant women, and the genetic variability of each population.

\section{Funding}

The study did not receive any funding.

\section{Conflict of interests}

The authors declare there is no conflict of interests.

\section{REFERENCES}

1. Christakos S, Dhawan P, Verstuyf A, Verlinden L, Carmeliet G. Vitamin D: metabolism, molecular mechanism of action, and pleiotropic effects. Physiol Rev. 2016;96:365-408. https://doi.org/10.1152/physrev.00014.2015

2. Hollis BW, Wagner CL. Vitamin D supplementation during pregnancy: Improvements in birth outcomes and complications through direct genomic alteration. Mol Cell Endocrinol. 2017;453:113-30. https://doi.org/10.1016/j. mce.2017.01.039

3. Pligt P, Willcox J, Szymlek-Gay EA, Murray E, Worsley A, Daly RM. Associations of maternal vitamin D deficiency with pregnancy and neonatal complications in developing countries: a systematic review. Nutrients. 2018;10:640. https://doi.org/10.3390/nu10050640

4. Wolsk HM, Harshfield BJ, Laranjo N, Hollis BW, Weiss ST, Litonjua $A A$, et al. Vitamin D supplementation in pregnancy, prenatal 25(OH)D levels, race, and subsequent asthma or recurrent wheeze in offspring: secondary analyses from the Vitamin D antenatal asthma reduction trial. J Allergy Clin Immunol. 2017;140:1423-9. https://doi.org/10.1016/j. jaci.2017.01.013

5. Maeda SS, Borba VZ, Camargo MB, Silva DM, Borges JL, Bandeira $F$, et al. Recommendations of the Brazilian Society of Endocrinology and Metabology (SBEM) for the diagnosis and treatment of hypovitaminosis D. Arq Bras Endocrinol
Metab. 2014;58:411-33. http://dx.doi.org/10.1590/00042730000003388

6. Roth DE, Abrams SA, Aloia J, Bergeron G, Bourassa MW, Brown $\mathrm{KH}$, et al. Global prevalence and disease burden of vitamin $D$ deficiency: a roadmap for action in low- and middle-income countries. Ann N Y Acad Sci. 2018;1430:4479. https://doi.org/10.1111/nyas.13968

7. Karras SN, Fakhoury H, Muscogiuri G, Grant WB, Ouweland JM, Colao AM, et al. Maternal vitamin D levels during pregnancy and neonatal health: evidence to date and clinical implications. Ther Adv Musculoskelet Dis. 2016;8:124-35. https://doi.org/10.1177/1759720X16656810

8. World Health Organization. Guideline: Vitamin D supplementation in pregnant women. Geneva: WHO; 2012.

9. Ercole FF, Melo LS, Alcoforado CL. Integrative review versus systematic review. Rev Min Enferm. 2014;18:09-11. https:// doi.org/10.5935/1415-2762.20140001

10. Brooke OG, Brown IR, Bone CD, Carter ND, Cleeve HJ, Maxwell JD, et al. Vitamin D supplements in pregnant Asian women: effects on calcium status and fetal growth. Br Med J. 1980;280:751-4. https://doi.org/10.1136/bmj.280.6216.751

11. Roth DE, Al Mahmud A, Raqib R, Akhtar E, Perumal N, Pezzack $B$, et al. Randomized placebo-controlled trial of high-dose prenatal third-trimester vitamin D3 supplementation in Bangladesh: the AViDD trial. Nutr J. 2013;12:47. https:// doi.org/10.1186/1475-2891-12-47 
12. Roth DE, Perumal N, Al Mahmud A, Baqui AH. Maternal vitamin D3 supplementation during the third trimester of pregnancy: effects on infant growth in a longitudinal follow-up study in Bangladesh. J Pediatr. 2013;163:160511. https://doi.org/10.1016/j.jpeds.2013.07.030

13. Asemi Z, Karamali M, Esmaillzadeh A. Favorable effects of vitamin D supplementation on pregnancy outcomes in gestational diabetes: a double blind randomized controlled clinical trial. Horm Metab Res. 2015;47:565-70. https://doi. org/10.1055/s-0034-1394414

14. Vaziri F, Dabbaghmanesh MH, Samsami A, Nasiri S, Shirazi PT. Vitamin D supplementation during pregnancy on infant anthropometric measurements and bone mass of mother-infant pairs: a randomized placebo clinical trial. Early Hum Dev. 2016;103:61-8. https://doi.org/10.1016/j. earlhumdev.2016.07.011

15. Abotorabi S, Poor S, Esmailzadehha N, Ziaee A, Khoeiniha $M$. Effect of treatment with vitamin D on maternal and neonatal indices in pregnant women with hypocalcemia: a randomized controlled trial. Int J Pediatr. 2017;5:5733-9. https://doi.org/10.22038/IJP.2017.22146.1851

16. Hashemipour S, Ziaee A, Javadi A, Movahed F, Elmizadeh K, Javadi $E H$, et al. Effect of treatment of vitamin D deficiency and insufficiency during pregnancy on fetal growth indices and maternal weight gain: a randomized clinical trial. Eur J Obstet Gynecol Reprod Biol. 2014;172:15-9. https://doi. org/10.1016/j.ejogrb.2013.10.010

17. Roth DE, Morris SK, Zlotkin S, Gernand AD, Ahmed T, Shanta SS, et al. Vitamin D supplementation in pregnancy and lactation and infant growth. N Engl J Med. 2018;379:53546. https://doi.org/10.1056/NEJMoa1800927

18. Kalra P, Das V, Agarwal A, Kumar M, Ramesh V, Bhatia E, et al. Effect of vitamin D supplementation during pregnancy on neonatal mineral homeostasis and anthropometry of the newborn and infant. Br J Nutr. 2012;108:1052-8. https:// doi.org/10.1017/S0007114511006246

19. Delvin EE, Salle BL, Glorieux FH, Adeleine P, David LS. Vitamin D supplementation during pregnancy: effect on neonatal calcium homeostasis. J Pediatr. 1986;109:328-34. https:// doi.org/10.1016/s0022-3476(86)80396-1

20. Yu CK, Sykes L, Sethi M, Teoh TG, Robinson S. Vitamin D deficiency and supplementation during pregnancy. Clin Endocrinol (Oxf). 2009;70:685-90. https://doi.org/10.1111/ j.1365-2265.2008.03403.x

21. Roth DE, Al Mahmud $A$, Raqib R, Black RE, Baqui $A H$. Pharmacokinetics of a single oral dose of vitamin D3 $(70,000 \mathrm{IU})$ in pregnant and non-pregnant women. Nutr J. 2012;11:114. https://doi.org/10.1186/14752891-11-114

22. Hashemipour S, Lalooha F, Zahir Mirdamadi S, Ziaee A, Dabaghi Ghaleh T. Effect of vitamin D administration in vitamin D-deficient pregnant women on maternal and neonatal serum calcium and vitamin D concentrations: a randomised clinical trial. Br J Nutr. 2013;110:1611-6. https:// doi.org/10.1017/s0007114513001244

23. Roth DE, Al Mahmud A, Raqib R, Akhtar E, Black RE, Baqui AH. Pharmacokinetics of high-dose weekly oral vitamin D3 supplementation during the third trimester of pregnancy in Dhaka, Bangladesh. Nutrients. 2013;5:788-810. https:// doi.org/10.3390/nu5030788
24. Roth DE, Mahmud AA, Raqib R, Baqui AH. Effects of highdose antenatal 3rd-trimester vitamin $D$ supplementation (35,000 IU/week) on maternal and newborn vitamin D status: a randomized placebo-controlled trial in Dhaka, Bangladesh. Faseb J. 2012;26 (Suppl 1):392-3. https://doi.org/10.1096/ fasebj.26.1 supplement.392.3

25. Shakiba M, Iranmanesh MR. Vitamin D requirement in pregnancy to prevent deficiency in neonates: a randomised trial. Singapore Med J. 2013;54:285-8. https://doi. org/10.11622/smedj.2013110

26. Wagner CL, McNeil RB, Johnson DD, Hulsey TC, Robinson C, Hamilton SA, et al. Health characteristics and outcomes of two randomized vitamin D supplementation trials during pregnancy: a combined analysis. J Steroid Biochem Mol Biol. 2013;136:313-20. https://doi.org/10.1016/j. jsbmb.2013.01.002

27. Dawodu A, Saadi HF, Bekdache G, Javed Y, Altaye M, Hollis BW. Randomized controlled trial (RCT) of vitamin D supplementation in pregnancy in a population with endemic vitamin D deficiency. J Clin Endocrinol Metab. 2013;98:2337-46. https://doi.org/10.1210/jc.2013-1154

28. Mutlu GY, Ozsu E, Kalaca S, Yuksel A, Pehlevan Y, Cizmecioglu $\mathrm{F}$, et al. Evaluation of vitamin D supplementation doses during pregnancy in a population at high risk for deficiency. Horm Res Paediatr. 2014;81:402-8. https://doi.org/10.1159/000358833

29. Hossain N, Kanani FH, Ramzan S, Kausar R, Ayaz S, Khanani R, et al. Obstetric and neonatal outcomes of maternal vitamin D supplementation: results of an open-label, randomized controlled trial of antenatal vitamin D supplementation in Pakistani women. J Clin Endocrinol Metab. 2014;99:244855. https://doi.org/10.1210/jc.2013-3491

30. Grant CC, Stewart AW, Scragg R, Milne T, Rowden J, Ekeroma $A$, et al. Vitamin D during pregnancy and infancy and infant serum 25-hydroxyvitamin D concentration. Pediatrics. 2014;133:e143-53. https://doi.org/10.1542/peds.2013-2602

31. Rodda CP, Benson JE, Vincent AJ, Whitehead CL, Polykov A Vollenhoven B. Maternal vitamin D supplementation during pregnancy prevents vitamin $D$ deficiency in the newborn: an open-label randomized controlled trial. Clin Endocrinol (Oxf). 2015;83:363-8. https://doi.org/10.1111/cen.12762

32. Sablok A, Batra A, Thariani K, Batra A, Bharti R, Aggarwal $A R$, et al. Supplementation of vitamin $D$ in pregnancy and its correlation with feto-maternal outcome. Clin Endocrinol (Oxf). 2015;83:536-41. https://doi.org/10.1111/cen.12751

33. March KM, Chen NN, Karakochuk CD, Shand AW, Innis SM, Dadelszen $\mathrm{P}$, et al. Maternal vitamin $\mathrm{D}_{3}$ supplementation at $50 \mu \mathrm{g} / \mathrm{d}$ protects against low serum 25-hydroxyvitamin $D$ in infants at 8 wk of age: a randomized controlled trial of 3 doses of vitamin $D$ beginning in gestation and continued in lactation. Am J Clin Nutr. 2015;102:402-10. https://doi. org/10.3945/ajcn.114.106385

34. Wall CR, Stewart AW, Camargo CA Jr, Scragg R, Mitchell EA, Ekeroma A, et al. Vitamin D activity of breast milk in women randomly assigned to vitamin D3 supplementation during pregnancy. Am J Clin Nutr. 2016;103:382-8. https:// doi.org/10.3945/ajcn.115.114603

35. Perumal N, Al Mahmud A, Baqui AH, Roth DE. Prenatal vitamin D supplementation and infant vitamin $D$ status in Bangladesh. Public Health Nutr. 2017;20:1865-73. https:// doi.org/10.1017/s1368980015003092 
36. Thiele DK, Ralph J, El-Masri M, Anderson CM. Vitamin D3 supplementation during pregnancy and lactation improves vitamin D status of the mother-infant dyad. J Obstet Gynecol Neonatal Nurs. 2017;46:135-47. https://doi.org/10.1016/j. jogn.2016.02.016

37. Motamed S, Nikooyeh B, Kashanian M, Hollis BW, Neyestani TR. Efficacy of two different doses of oral vitamin D supplementation on inflammatory biomarkers, and maternal and neonatal outcomes. Matern Child Nutr. 2019;15:e12867. https://doi.org/10.1111/mcn.12867

38. Enkhmaa D, Tanz L, Ganmaa D, Enkhtur S, Oyun-Erdene B, Stuart J, et al. Randomized trial of three doses of vitamin $D$ to reduce deficiency in pregnantMongolian women. EBioMedicine. 2019;39:510-9. https://doi.org/10.1016/j.ebiom.2018.11.060

39. Harrington J, Perumal N, Al Mahmud A, Baqui A, Roth DE. Vitamin D and fetal-neonatal calcium homeostasis: findings from a randomized controlled trial of high-dose antenatal vitamin D supplementation. Pediatr Res. 2014;76:302-9. https://doi.org/10.1038/pr.2014.83

40. Diogenes ME, Bezerra FF, Rezende EP, Donangelo CM. Calcium plus vitamin D supplementation during the third trimester of pregnancy in adolescents accustomed to low calcium diets does not affect infant bone mass at early lactation in a randomized controlled trial. J Nutr. 2015;145:1515-23. https://doi.org/10.3945/jn.114.208140

41. Cooper C, Harvey NC, Bishop NJ, Kennedy S, Papageorghiou AT, Schoenmakers I, et al. Maternal gestational vitamin D supplementation and offspring bone health (MAVIDOS): a multicentre, double-blind, randomised placebo-controlled trial. Lancet Diabetes Endocrinol. 2016;4:393-402. https:// doi.org/10.1016/S2213-8587(16)00044-9

42. Sahoo SK, Katam KK, Das V, Agarwal A, Bhatia V. Maternal vitamin D supplementation in pregnancy and offspring outcomes: a double-blind randomized placebo-controlled trial. J Bone Miner Metab. 2017;35:464-71. https://doi. org/10.1007/s00774-016-0777-4

43. Nørrisgaard PE, Haubek D, Kühnisch J, Chawes BL, Stokholm $\mathrm{J}$, Bønnelykke $\mathrm{K}$, et al. Association of high-dose vitamin D supplementation during pregnancy with the risk of enamel defects in offspring: a 6-year follow-up of a randomized clinical trial. JAMA Pediatr. 2019;173:924-30. https://doi. org/10.1001/jamapediatrics.2019.2545

44. Grant CC, Kaur S, Waymouth E, Mitchell EA, Scragg R, Ekeroma $A$, et al. Reduced primary care respiratory infection visits following pregnancy and infancy vitamin $D$ supplementation: a randomised controlled trial. Acta Paediatr. 2015;104:396404. https://doi.org/10.1111/apa.12819

45. Grant CC, Crane J, Mitchell EA, Sinclair J, Stewart A, Milne $\mathrm{T}$, et al. Vitamin D supplementation during pregnancy and infancy reduces aeroallergen sensitization: a randomized controlled trial. Allergy. 2016;71:1325-34. https://doi. org/10.1111/all.12909

46. Chawes BL, Bønnelykke K, Stokholm J, Vissing NH, Bjarnadóttir E, Schoos AM, et al. Effect of Vitamin D3 supplementation during pregnancy on risk of persistent wheeze in the offspring: a randomized clinical trial. JAMA. 2016;315:35361. https://doi.org/10.1001/jama.2015.18318

47. Mirzakhani H, Al-Garawi AA, Carey VJ, Qiu W, Litonjua AA Weiss ST. Expression network analysis reveals cord blood vitamin D-associated genes affecting risk of early life wheeze. Thorax. 2019;74:200-2. http://dx.doi.org/10.1136/ thoraxjnl-2018-211962

48. Schoos AM, Vinther C, Nørgaard S, Brustad N, Stokholm J, Bonnelykke K, et al. Environmental and genetic determinants of serum 25(oh)-vitamin D levels during pregnancy and early childhood. Children (Basel). 2019;6:116. https://doi. org/10.3390/children6100116

49. Griffiths M, Goldring S, Griffiths C, Shaheen SO, Martineau A, Cross $L$, et al. Effects of pre-natal vitamin D supplementation with partial correction of vitamin d deficiency on early life healthcare utilisation: a randomised controlled trial. PLoS One. 2015;10:e0145303. https://doi.org/10.1371/journal. pone. 0145303

50. Anderson CM, Gillespie SL, Thiele DK, Ralph JL, Ohm JE. Effects of maternal vitamin D supplementation on the maternal and infant epigenome. Breastfeed Med. 2018;13:371-80. https://doi.org/10.1089/bfm.2017.0231

51. Newton DA, Baatz JE, Kindy MS, Gattoni-Celli S, Shary JR, Hollis BW, et al. Vitamin D binding protein polymorphisms significantly impact vitamin D status in children. Pediatr Res. 2019;86:662-9. https://doi.org/10.1038/s41390-019-0322-y

52. Bilic M, Qamar H, Onoyovwi A, Korsiak J, Papp E, Mahmud A et al. Prenatal vitamin D and cord blood insulin-like growth factors in Dhaka, Bangladesh. Endocr Connect. 2019;8:74553. https://doi.org/10.1530/EC-19-0123

53. Sordillo JE, Zhou Y, McGeachie MJ, Ziniti J, Lange N, Laranjo $\mathrm{N}$, et al. Factors influencing the infant gut microbiome at age 3-6 months: findings from the ethnically diverse Vitamin D Antenatal Asthma Reduction Trial (VDAART). J Allergy Clin Immunol. 2017;139:482-91. https://doi.org/10.1016/j. jaci.2016.08.045

54. Akinlaja O. Hematological changes in pregnancy - the preparation for intrapartum blood loss. Obstet Gynecol Int J. 2016;4:00109. https://doi.org/10.15406/ogij.2016.04.00109

55. Liu NQ, Hewison M. Vitamin D, the placenta and pregnancy. Arch Biochem Biophys. 2012;523:37-47. https://doi. org/10.1016/j.abb.2011.11.018 